\title{
AZ INNOVÁCIÓS EGYÜTTMÜKÖDÉS OKAI ÉS TÍPUSAI A VEGYIPARBAN
}

Modern nemzetgazdaságokban az innovációs tevékenység kritikus, versenyelônyt meghatározó tényezốvé vált. A tudásfolyamatok egyre komplexebbé válásával a vállalatok határaikon túlnyúló kapcsolatok kialakítására kényszerülnek, amelyek révén pótlólagosan kiegészítố erốforrásokhoz jutnak. Az egyre rövidüló termék- és technológiai életciklusok következtében a cégek innovációs stratégiájuk újragondolására kényszerültek. Így a vállalati együttmúkködés egyre hangsúlyosabb szerepet kapott a cégek innovációs stratégiájában és folyamatában. Magyarországon a vegyipar a tudás- és innovációintenzív ágazatok közé tartozik. A fejlesztési és innovációs törekvések elsôsorban a vegyipari termékek használati értékére, minőségére és árára fókuszálnak, azonban az elơállított termékek és technológiák gazdaságosságával szembeni követelmények, a környezeti hatások csökkentésére (újrahasznosítás, lebonthatóság) vonatkozó igények is egyre nagyobb hangsúlyt kapnak. Mindez folyamatos kutatás-fejlesztést és innovatív szemléletmódot kíván meg a vegyipari vállalatok részéról. A fejlesztés szellemi és infrastrukturális igényei rendkívül nagyok, ezért a szükséges tudományos ismeretek és berendezések sok esetben nem egyetlen cégnél állnak rendelkezésre, ezért egyre gyakoribb a vállalatközi együttmúködés a vegyipari innovációs tevékenység területén.

\section{Kulcsszavak: innováció, vegyipar, együttmúködések, Magyarország}

Napjainkban a cégek és nemzetgazdaságok tekintetében az innováció elengedhetetlenül fontos versenyképességi tényezónek számít. Az innováció meghatározására számos megközelítés létezik. A definíciók osztályozási rendszerében talán a Zaltman-Duncan-Holbeckféle csoportosítás a leginkább összefogott (Zaltman - Duncan - Holbeck, 1973). Véleményük szerint az innováció a következő három kategória egyikébe sorolható (a kategóriák árnyaltabb magyarázatához a Zaltman - Duncan - Holbeck által kidolgozott eredeti osztályozást más szerzók innovációdefinícióival is bővítettem): 1. Az új termék/technológia és a technológia fejlesztési folyamata. Az innováció ez esetben a kreatív fejlesztési folyamatra utal. Ez az a folyamat, amely a potenciális kereslet felismerésével kezdődik és a technológiai megvalósíthatóság megléte esetén annak széles körú hasznosításával zárul. Az innováció olyan kreatív folyamatnak tekinthetô, melynek eredményeként valami új keletkezik. Holt (1983: p. 13.) az előző megközelítést alkalmazva új megvilágításba helyezi az innováció fogalmát, mert szerinte ,az a folyamat, amely a tudás vagy releváns információk segítségével valami újat és használhatót hoz létre és tesz alkalmazhatóvá”. Ugyanezt a szemléletmódot képviselte Haeffner (1973: p. 20.) is, mert ô az innovációt olyan ,irracionális folyamatként ábrázolta, ahol az innovációs ötlet jelenik meg először, és hoszszú, körülményes fejlódési folyamat eredményeként jön létre a késztermék". Az innováció fogalmának legtöbb meghatározása ebbe a kategóriába tartozik.

2. Az új termék/technológia adaptációja. Ebbe a kategóriába azok a folyamatok tartoznak, amelyek egy másik piaci szereplő által bevezetett termék/technológia alkalmazására épülnek. Knight (1967: p. 487.) meghatározása szerint az innováció „mind a szervezet, mind pedig a releváns környezet számára valami új adaptációját jelenti”.

3. Maga az új termék/technológia. Az innováció harmadik kategóriája mindazon termékre és technológiára utal, amely egy eddig még ismeretlen, teljesen új fejlesztés, találmány eredményének tekinthetô. Míg a két korábbi nézet az innovációt mint folyamatot vizsgálta, addig a harmadik az innovációt egy folyamat eredményének tekinti. Zaltman - Duncan 
- Holbeck (1973: p. 10.) szerint az innováció olyan „ötlet, alkalmazás vagy termék, amely a releváns személy, szervezeti egység vagy szervezet számára új”. E véleménnyel teljes egészében azonosul Rogers (1983: p. 11.) is. E szerzók az innovációt az adaptáló szempontjából vizsgálták.

Megállapítható, hogy az elóbbiekben bemutatott meghatározások nagyon közel állnak egymáshoz. Az elsố szemléletmód az innovációt a fejlesztô egység szemszögéból vizsgálja. A fejlesztő egység lehet egy gazdasági társaság, társadalmi szervezet, vagy akár egy személy is. A második megközelítés abban különbözik az előzótól, hogy az innovációt nem a fejlesztô, hanem az adaptáló egység szemszögéból vizsgálja. Egyes speciális esetekben a fejlesztó és adaptáló egység megegyezhet (például, ha a vállalat a berendezést belsố használatra fejleszti ki). Egyértelmúen látható a harmadik megfogalmazás esetében, hogy az magára a termékre vagy technológiára koncentrál.

Ezzel kapcsolatban Rogers és Schoemaker (1971: p. 19.) annak a véleménynek adott hangot, hogy ,az emberi magatartásból adódó ötlet újdonságértékének mérőszámát a felfedezésétől, vagy első használatától eltelt idő hossza csak egészen ritka esetben határozza meg... Ha az ötlet (az adaptáló egység szempontjából) új, vagy az eddigi gyakorlattól eltérō, akkor az innovációnak tekinthetô"'.

E szemléletmóddal nem minden szerző értett egyet, sốt van, aki támadta is azt. Ezek közé tartozik Becker és Whisler (1967: p. 463.), mivel ók az innovációt „folyamatként" definiálták. Véleményük szerint innovációról akkor beszélhetünk, ha a szervezet az első adaptálók között van, és ezzel jelentős költséget és kockázatot vállal. A késốbbi alkalmazók csak bizonyos mértékú változtatásokat hajtanak végre, de ezek már nem tekinthetôk innovációnak. Tehát amikor az innováció a diffúziós fázisba ér, akkor az már hagyományos értelemben véve nem innováció. Iványi és Hoffer szintén e nézet mellett száll síkra, hiszen innovációnak tekintik ,,a termelési folyamatban bevezetett technológiai fejlesztéseket és a piacképes termékek különböző tulajdonságainak és e tulajdonságok különböző kombinációinak bevezetését" (Iványi - Hoffer, 2004: p. 13.). Borsi (2004: p. 6.) szintén azt hangsúlyozza, hogy az innováció „egy ötlet átalakulása vagy a piacon bevezetett új, illetve korszerúsített termékké, vagy az iparban és kereskedelemben felhasznált új, illetve továbbfejlesztett múveletté, vagy valamely társadalmi szolgáltatás újfajta megközelítése".

Összefoglalva elmondható, hogy az innováció a tudásgenerálás során megvalósuló interaktív folyamat. $\mathrm{Az}$ interakciót több szinten lehet értelmezni, például az innovatív miliő oldaláról (Camagni, 1991), a tudás spilloverek tekintetében (Botazzi - Peri, 2003), az innovációs hálózatok oldaláról (Powell - Grodal, 2005), vagy éppen az innovációs rendszerek viszonylatából (Edquist, 2005).

\section{A vegyipar helyzete hazánkban}

A gazdasági világválság rendkívül érzékenyen érintette a vegyipari szektort. Iparági felmérések szerint a válságot követố recesszió leginkább a közép-kelet-európai régióban tevékenykedő cégekre gyakorolt hatást, és itt esett vissza leginkább az ágazat teljesítménye. A válságot követôen a felvevốpiacok fellendülésével a régióban, így hazánkban is, fokozatosan talpra állt az iparág, amely azonban így is minden kétséget kizárólag az évezred eddigi legrosszabb évét zárta 2009-ben, és feltételezhetôen még sokáig nem lesz képes visszaállni a korábbi növekedési ütemre.

Magyarországon a vegyipar termelése az elôzetes várakozásoknál kisebb mértékben, de jelentôsen csökkent a válság legsúlyosabb évében. Az ágazat kibocsátása (a gyógyszeripari termelés nélkül) - a Magyar Vegyipari Szövetség (Mavesz) adatai szerint - folyó áron 2537 milliárd forint volt, ami az előző évinél majd 23 százalékkal kevesebb (http://ecoline.hu/piac/20101001_vegyipar_elemzes.aspx), de még a 2006-os szinttól is elmarad (lásd 1. ábra). A visszaesést fóként a termelés visszafogása, így a volumen csökkenése magyarázza, de a negatív árhatásra is visszavezethetô. Az iparág jövedelmezősége a korábbi évek töredékére csökkent, amihez nagyban hozzájárult az előállított végtermékek árainak esése.

A 2010-es esztendő mind termelésben, mind pedig jövedelmezôségben javulást hozott a regionális és a hazai vegyiparban, de a válság előtti szinttól még jócskán elmarad az ágazat teljesítménye. A javulás fóként az export erősödésének tudható be. Az exportorientált vállalatok könnyebben vészelték át a válságot, hiszen a hazai piac termékfelvevô képessége lassabban javult. Az iparág prominens képviselói szerint az unióban tevékenykedő vegyipari cégek sokkal nehezebb helyzetben vannak, hiszen az energiahordozók magas ára és a rendkívül szigorú EU-s környezetvédelmi szabályok jelentôs versenyhátrányt okozhatnak az unión kívüli konkurensekhez képest. Mindebból az következik, hogy az ágazat versenyképességének kulcsa a kutatásfejlesztésben és az innovációban rejlik.

Az innovációs tevékenységre jelentős hatást gyakorolnak a világ vegyiparát determináló tényezók, amelyek közé tartoznak többek között:

- a növekvő igény a környezeti terhelés csökkentésére, 
A vegyipari alágak termelési értéke 2001-2006 között

Mrd Ft

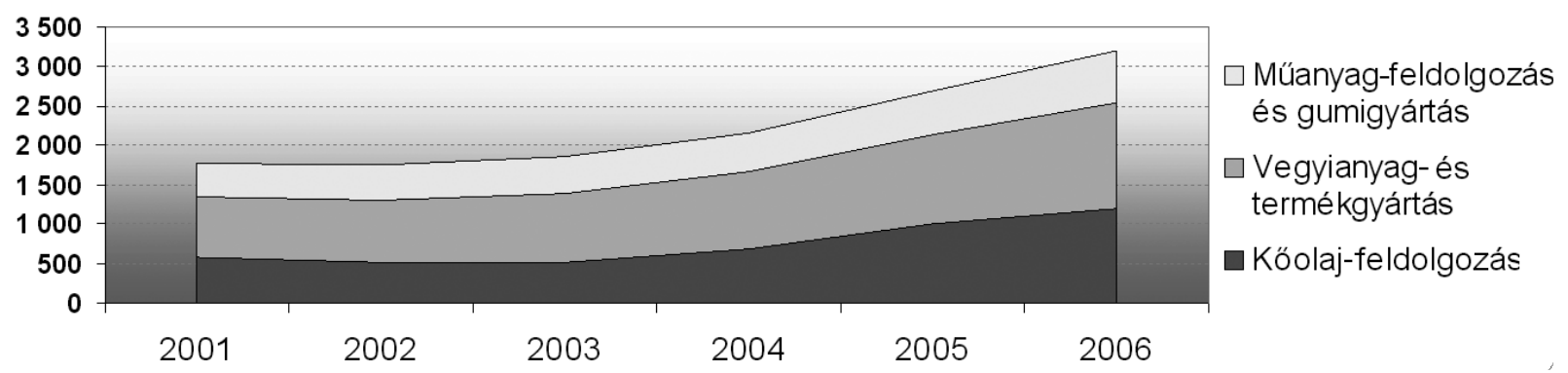

(Forrás: Olvasó, 2007)

- a globalizáció és technológiai transzfer,

- a profitelvárások,

- a munkaerô minőségével szembeni elvárások növekedése: a vegyipar munkaeróigénye folyamatosan átalakul.

A magyar vegyipar az európai vegyipari termeléshez csak kismértékben járul hozzá, az iparág követô szerepben és alkalmazkodási kényszerben van. Így a vegyipar legnagyobb kihívása a globális gazdasági hatásokból és az európai uniós vállalásból adódik.

Az Európai Unió vegyiparának innovációs tevékenységét vizsgáló tanulmány (Albach et al., 1996) az iparág viszonylatában a következő trendeket fogalmazta meg:

- kedvező költségstruktúrára való törekvés,

- meghatározott termékekre/termékcsoportokra való szakosodás,

- alaptevékenységre való összpontosítás,

- a globális versenyben stabil és tartós pozíció kialakítására való törekvés,

- vállalatok stratégiai együttmúködésének fejlesztése.

Mindebból az következik, hogy a vegyiparban tevékenykedő cégeknek kiemelt hangsúlyt kell helyezniük az innovációs potenciál erősítésére és a vállalati együttmúködés ösztönzésére.

\section{Innováció a vegyiparban}

A korszerú vegyipar a kutatás-fejlesztés intenzív iparágak közé tartozik. A növekvő fogyasztói elvárások innovációs versenyt generáltak a vegyiparban is (ICEG EC, 2004). A fogyasztói elvárások elsósorban a vegyipari termékek használati értékével, minőségével és árával kapcsolatosak, azonban a termékek és technológiák gazdaságosságával szembeni követelmények, a környezeti hatások csökkentésére (újrahasznosítás, lebonthatóság) vonatkozó igények is, egyre nagyobb hangsúlyt kapnak. Ez folyamatos fejlesztést és innovatív magatartást kíván meg a vegyipari cégek részéról.

A feldolgozóiparban foglalkoztatott kutatás-fejlesztésben dolgozók körülbelül 60 százaléka a vegyiparban dolgozik. A vegyiparban tevékenykedő nagyvállalatoknál hatékonyan múködő K+F szervezetek vannak, sốt a kutatóhelyek jelentôs részével is intenzív kapcsolatot építettek ki. Szépvölgyi (2005) tanulmánya szerint a vegyipar, valamint a vegyipari fejlesztések legfóbb elönyei között kell megemlíteni az életminőség javulását az innovatív technológiák kifejlesztését, de a környezetszennyezés csökkentése is fontos cél.

Ha az innováció technológiai oldalát mélyebben megvizsgáljuk, akkor elmondható, hogy a hazai vegyipar korszerú, költséghatékony és versenyképes technológiákat alkalmaz, amelynek egy része fejlett nyugateurópai országokból és Japánból származik, másrészt saját fejlesztésú technológiák is megjelennek, elsôsorban a gyógyszeriparban és a múanyagalapanyag-gyártásban. Mindebból az következik, hogy a hazai ipar egyik leginnovatívabb ágazata a vegyipar.

A kutatás-fejlesztésre alapozott innováció alapvetố célja a cég piaci helyzetének javítása. A lehetséges mozgásteret és a szükséges lépéseket alapvetôen a cég gazdasági ereje, valamint a külső feltételek alakulása határozza meg. Az innovációs célok, a technológiai színvonal és az üzleti lehetőségek közötti kapcsolatot a 2. ábra mutatja.

A célok a meglévő technológiai és üzleti potenciál kismértékú javításától a radikálisan új technológiák kifejlesztéséig, ezáltal a vállalat piaci helyzetének hirtelen megugró javulásáig terjedhetnek.

Az elmúlt évtizedben változás tapasztalható a kutatás-fejlesztési stratégiákban és paradigmaváltásra került sor az iparvállalatok többségénél (Szépvölgyi, 1999). 
Technológiai színvonal és az üzleti lehetôségek összefüggése

\begin{tabular}{|l|c|c|}
\cline { 2 - 3 } \multicolumn{1}{c|}{} & Meglévő üzleti lehetôség & Új üzleti lehetôség \\
\hline Új technológia & Következó generáció & Áttörés \\
\hline Meglévố technológia & Meglévő támogatás & Kiterjesztés \\
\hline
\end{tabular}

(Forrás: Szépvölgyi, 1999)

Az 1980-as évek vége az elsó generációs $K+F$ stratégiák kora. Ekkor az innovációs tevékenység központja a vállalatok kutató-fejlesztô részlege mind szakmai, mind pedig pénzügyi vonatkozásban. A kutatás-fejlesztéssel foglalkozó szakemberek döntenek a $\mathrm{K}+\mathrm{F}$ fókuszában álló témákról, és a cégvezetôk szinte automatikusan rendelkezésükre bocsátják az ezekhez szükséges pénzeszközöket. A „remény stratégiáinak” is nevezik ezt, hiszen a cégvezetốk csak reménykedni tudnak, hogy a kutatásfejlesztésre fordított összegek a jövőben megtérülnek.

A második generációs kutatás-fejlesztési stratégiák esetében már kiemelt hangsúly kap a gazdaságossági vetület. A $\mathrm{K}+\mathrm{F}$ programokat elózetes költség-haszon elemzések eredményeitôl teszik függóvé. A kutatás-fejlesztéssel kapcsolatos döntéseket a cég menedzsmentje hozza meg, és folyamatosan ellenôrzi az előzetesen kitúzött célokhoz mért elôrehaladást. A konkrét fejlesztési programokat viszont még a vállalat egyéb üzleti tevékenységétól függetlenül valósítják meg.

A mostanában is tapasztalható harmadik generációs kutatás-fejlesztési stratégiáknál a cégek a múszaki fejlesztést már összeegyeztetik a hosszú távú stratégiai érdekükkel. A K+F témákra ugyan a kutatás-fejlesztéssel foglalkozó szakemberek tesznek javaslatot, de a döntő szót a szakmai és gazdasági ügyekben a vállalat felsố vezetése mondja ki, közgazdasági és múszaki megfontolások alapján.

Napjainkban a kutatás-fejlesztés és innovációs tevékenység szellemi, valamint infrastrukturális igénye rendkívül nagy, ezért a szükséges tudományos szakismeret, a méréstechnikák egy része és a kísérleti berendezések sok esetben nem egyetlen cégnél állnak rendelkezésre, ebból adódóan egyre gyakoribb az együttmúködés a vegyipari fejlesztések területén.
Achilladelis et al. (2001) a vegyipari innovációk hét fố hajtóerejét különítette el:

- a tudományos és technológiai fejlődés (külsó adottság az innovációt végrehajtó cég számára),

- az alapanyagok (elérhetőségük vagy hiányuk),

- a piaci kereslet (az innovációt végrehajtó vállalat elózetesen felmér és értékel),

- a verseny (a konkuráló cégek tudományos, technológiai és marketingtevékenysége következtében),

- a társadalmi szükséglet (rendkívül nehéz megítélni a fejlesztés és a piacra dobási folyamat előtt),

- a kormányzati szabályozás (ami befolyásolja a cégek $\mathrm{K}+\mathrm{F}$ tevékenységét és a fennálló versenyhelyzetet),

- a vállalat tudományos, technológiai, piaci specializációja (amit múltbeli tevékenysége determinál).

Ezek a hajtóerốk nem elkülönülten múködnek, de az innovációra eltérố mértékben hatnak. Az első hat tényezó „környezeti” faktorként is felfogható, és hatást gyakorol a kutatásintenzív vállalatokra. A hetedik „vállalatspecifikus” és hosszú távon jelentősen kihat a cég innovációs tevékenységére. A „környezeti” tényezók hatására a kutatásintenzív szektorokban tevékenykedố cégek saját berkeiken belül is kifejlesztenek olyan képességeket, és esetleg külön szervezeti egysé-

\section{Az innováció hajtóerối}

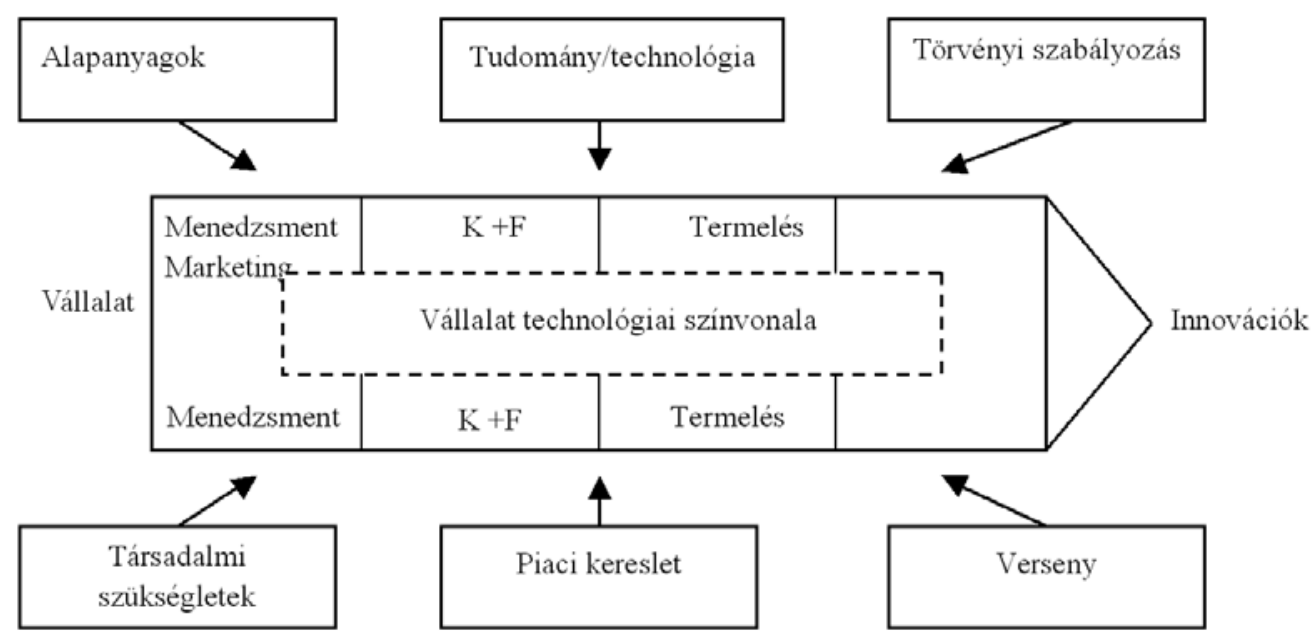

(Forrás: Achilladelis et al., 2001) 
geket (például $\mathrm{K}+\mathrm{F}$ részleg, értékesítés, marketing- és jogi osztály), amelyek segítségével hatékonyan tudnak reagálni a külsô faktorok (tudomány és technológia fejlódése, új alapanyagok hasznosítására, piaci kereslet és verseny változása) kihívásaira. A 3. ábra mutatja a hatóerôk közötti interakciók összefüggéseit az innovatív vállalatok esetén (3. ábra).

\section{Innovációs együttmúködés a vegyiparban tevékenykedó cégek között}

Az említett vegyipari specifikumok arra inspiráltak, hogy kutatást végezzek a hazánkban tevékenykedő vegyipari vállalatok körében, kiemelt figyelmet fordítva az innovációs együttmúködésre. A vegyiparban 101 vállalatot kerestem fel. A vállalatokat a vegyipari szövetség elnökével egyeztetve válogattam ki. Így próbáltam az iparágat és annak jellegzetességeit húen tükröző cégeket elemzésembe vonni.

A vegyipari innováció és innovációs együttmúködés specifikumait kutatva kíváncsi voltam arra, hogy a hazai vállalatoknál miképpen valósul meg a cégek közötti kooperáció. Kutatások igazolják, hogy az innovációs vállalati együttmúködés formái kategorizálhatók. Az osztályozást eltérô rendezóelvek szerint lehet végrehajtani. Auster (1987) a vállalati kapcsolatokat három nagy csoportra osztja. Megkülönböztet technológiatranszfert és/vagy technológiacserét, $\mathrm{K}+\mathrm{F}$ együttmúködést, valamint vegyes vállalatot. Chesnais (1988) a vállalatközi együttmúködési megállapodások taxonómiáját mutatja be, amelyre a kormányzati érdekek, a technológia, a tốkeszükséglet és az iparági struktúra gyakorol hatást.

Ezzel szemben Harrigan (1985) a tulajdonlás és az ellenőrzés foka szerinti kategorizálást alkalmazza. Míg Contractor és Lorange (1988) az együttmúködési megállapodásokat tartományuk (azaz kitúzött céljuk és földrajzi dimenziójuk) szerint csoportosítja. Hagedoorn $(1989,2002)$ a korábbi klasszifikációkat ötvözve a partnerkapcsolatra lépó vállalatok közötti függőségi viszony szerinti csoportosítást alkalmazza, sốt kifejezetten a technológiatranszfer, a technológiamegosztás, a kutatás-fejlesztési együttmúködés, általánosan fogalmazva az innovációcentrikus kooperációra terjeszti ki vizsgálatát. Az együttmúköóés számának és relevanciájának növekedéséhez számos tényezô hozzájárul (Contractor - Lorange, 1988; Hagedoorn - Schakenraad, 1989), így például:

- a piacok nemzetközivé válása,

- a technológiai fejlődés ütemének felgyorsulása, növekvő komplexitása és fokozott bizonytalansága,

- az egyre növekvő kutatás-fejlesztési költségek,
- a nagyvállalatok azon törekvése, hogy a technológia teljes spektrumát minél inkább befolyásuk alá vonják.

Ahhoz, hogy a vállalatok közötti kooperációt elemezni lehessen, elengedhetetlen az együttmúködési megállapodás pontos definiálása. Mariti és Smiley (1983) szerint az együttmúködési megállapodás két vagy több vállalat közötti hosszú távú, formalizált megegyezés. Vonatkozhat termék vagy szolgáltatás értékesítésére, de információ, termék vagy szolgáltatás cseréjére is. A kritérium, aminek meg kell felelni, hogy hosszú távra vonatkozzon az együttmúködés. A kooperációs megállapodások létrejöhetnek szóban is, de legtipikusabb formája írásban rögzített.

A vállalatközi együttmúködési formák egyik legárnyaltabb kategorizálását Hagedoorn (1990) adja. Megkülönböztet:

- vegyes vállalatot (illetve kutatásra szakosodott nagyvállalatot),

- K+F megállapodást,

- technológiacserére irányuló megegyezést,

- közvetlen tókeberuházást,

- megrendeló-beszállító kapcsolatot és

- egyirányú technológiaáramlást.

Mindegyik együttmúködési forma hatást gyakorol az alkalmazott technológiára, illetve annak vállalatok közötti megosztására, a szervezeti struktúrára, a társuló partnerek gazdasági helyzetére és a partnerek innovációs képességére. A 4. ábráról könnyen leolvasható, hogy az egyirányú technológiaáramlás esetén a legkisebb az egymásrautaltság mértéke és az ellenórzés foka. A vegyes vállalatnál és a kutató nagyvállalatnál viszont rendkívül szoros a kapcsolat a kooperáló felek között a vizsgált dimenziókban (4. ábra).

A vállalati hálózatok meghatározására számos definíció létezik (Freeman, 1991; Quinn, 1992; Seufert et al., 1999; Trenti, 1996). Mindegyik kutató az általa végzett vizsgálat fókusza, egyedi megközelítése szerint definiálja az együttmúködési megállapodásokat. Trenti (1996) például minden kettő vagy annál több cég közötti kapcsolatot kooperációnak tekint, amelyet meghatározott időszakon keresztüli erőforrás-megosztás jellemez egy vagy több termék és/vagy technológia kifejlesztése, piaci bevezetése és terjesztése céljából. E meghatározás kulcspontja az erőforrás-megosztáson van, amely túlmutat az eróforrástranszfert hangsúlyozó definíciókon. Átfogó definíciót adnak Seufert és szerzőtársai (1999), akik úgy látják, hogy a hálózatot személyek, csoportok és szervezetek összessége között lehet értelmezni. A kialakult kapcsolatokat pedig tartalmuk (például termékek, szolgáltatások vagy információ), formájuk 
Együttmúködési megállapodások típusai az ellenốrzés foka és az egymásrautaltság tekintetében

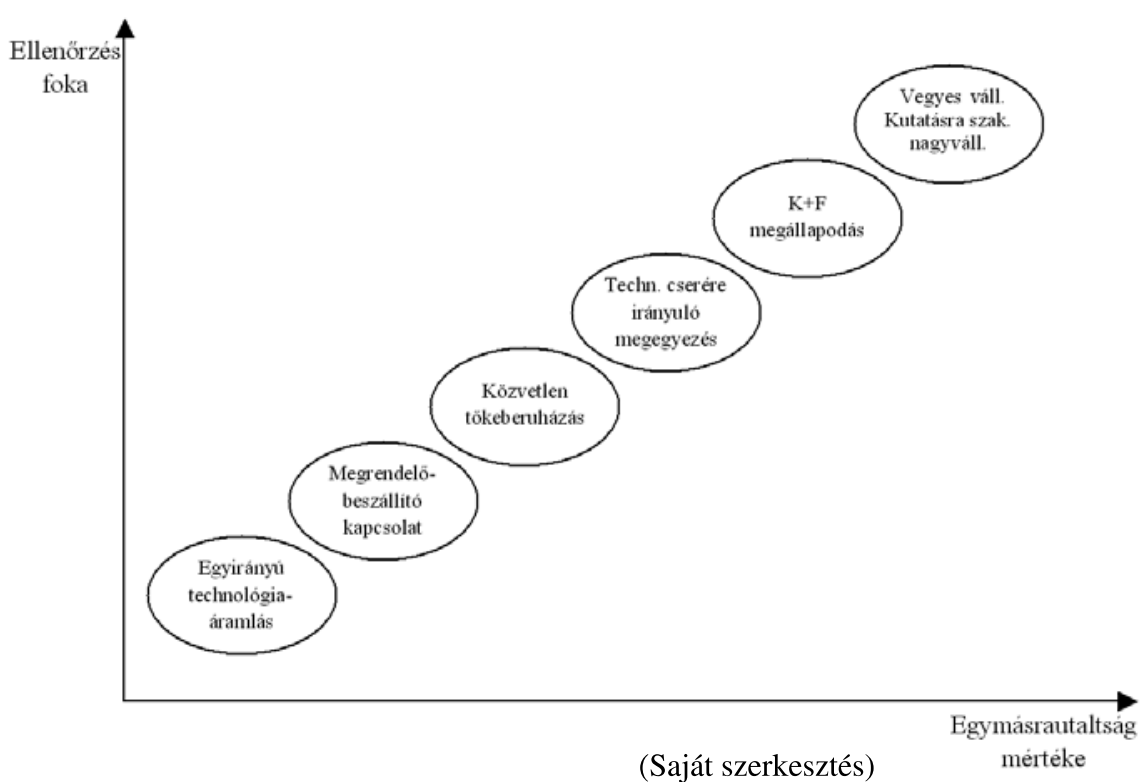

4. ábra 1988). Ez az oka, hogy a kooperáló vállalatok megpróbálják minimalizálni az opportunista magatartást, és a hangsúlyt a bizalom és a jó hírnév jelentôségére helyezik (Killing, 1983).

Amikor a kooperáció jellegét próbáltam feltárni, érdekes eredményre jutottam. A vállalatok szinte fele (44 százaléka) megrendelő-beszállítói viszonyt alakított ki partnerével (5. ábra). Erre az eredményre már nagymértékben hatást gyakorolt az a tény, hogy a cégek 54 százaléka az ügyfeleket jelölte meg legfontosabb innovációs információforrásként. Mindez azt sugallja, hogy a vegyiparban a vállalatok célirányos fejlesztéseket hajtanak végre, és kifejezetten a partner igényeinek megfelelóen hajtják végre azt.

A mintában igen nagy arányt képviselt még a kutatás-fejlesztési megállapodás is. A cégek 38 százaléka vélte elsődlegesnek ezt a típusú együttmúködési formát. Az innovációs megállapodás már kevésbé volt gyakori az interjúalanyaim vállalatai esetében, csak a minta 11 százaléka ismerte el ezt a fajta kooperációt a legfontosabb együttmúködési formának. Ez az eredmény arra enged következtetni, hogy a cégek inkább az innovációs folyamat egy-egy szakaszára lépnek együttmúködésre egymással, a teljes innovációs folyamatban már kevéssé jellemezô a kooperáció. A közös vállalat, a licencmegállapodás, valamint a tech-

5. ábra

Vállalati innovációs

együttmúkködések formái a vegyiparban részvényeseknek és a cég érdekszférájába tartozóknak).

Mindebból az következik, hogy az együttmúködési megállapodás olyan vállalatközi kapcsolatként fogható fel, amely a kitüzött célok elérése, a kockázat minimalizálása, valamint az egymás iránti bizalom és elkötelezettség megvalósítása érdekében jön létre. Az együttmúködés révén a vállalatok fokozhatják erósségeiket és minimalizálhatják - a többiek segítségével - gyengeségeiket, így a társuló felek együttesen hosszú távú versenyelónyre tehetnek szert (Contractor - Lorange,

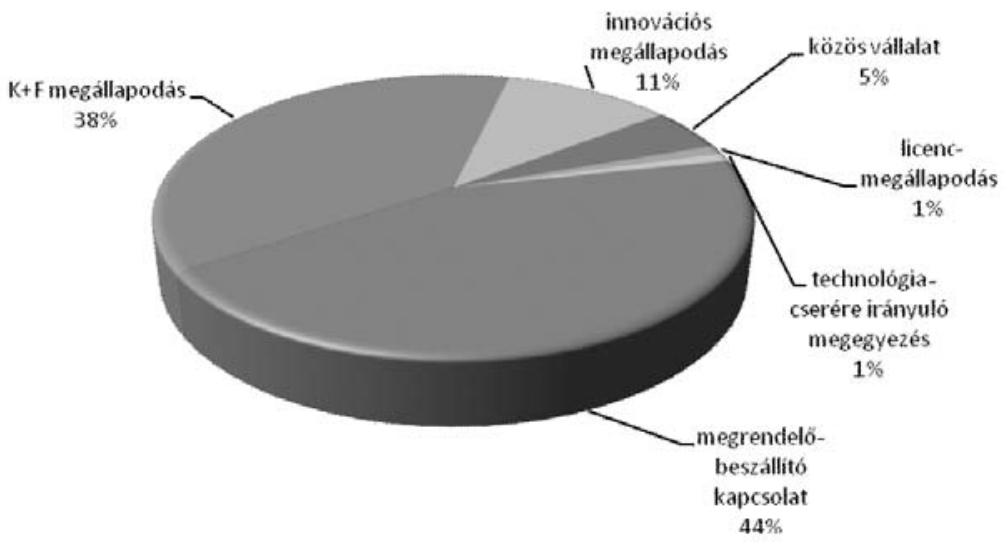

(Saját szerkesztés) 
nológiacserére irányuló megegyezés már kevésbé volt népszerú partnerkapcsolat-típus, hiszen a cégek 5, illetve 1-1 százaléka tekintette azt dominánsnak (5. ábra).

A kutatás során kiderült, hogy a vállalatok 72 százaléka személyes ismeretség alapján választott innovációs partnert, tehát látható, hogy az együttmúködő felek kiemelt figyelmet szentelnek annak, hogy a partnert alaposan megismerjék, és csak utána lépnek vele komolyabb tranzakcióba. A minta 12 százaléka kiállításokon és bemutatókon ismerkedett meg a kooperáló féllel. A szaklapokat, publikációkat említették harmadik helyen a válaszadók, és ezt követően, a partner megismerésében, azonos súllyal jelent meg a rendezvény és az adatbank. Két cégnek - amelyek nagy multinacionális külföldi cégek leányvállalatai - az anyavállalata határozta meg, hogy kivel léphet innovációs együttmúködésre.

A vegyiparban tevékenykedő vállalatoknak leginkább a technológiai versenyképesség emelkedésében jelentett elônyt a kooperáció. Az együttmúködést követően azonban a vállalat hírneve és $\mathrm{K}+\mathrm{F}$ hatékonysága is jelentősen növekedett.

Amennyiben a mintában szereplő vállalatok fó profilját elemzem, akkor megállapítható, hogy a cégek 77 százaléka az elóállítást, gyártást, 14 százaléka a marketing és értékesítést, 9 százaléka pedig a kutatás-fejlesztést tekinti fó tevékenységének.

Érdekes volt megvizsgálni, hogy a vegyipari cégeknél dolgozó kutatók munkaideje miként oszlik meg. A kutatók átlagosan idejük 45 százalékát alkalmazott kutatással, 35 százalékát pedig kísérleti fejlesztéssel töltik. A kutatók átlagos munkaidejének 5 százalékát a technológiatranszfer tölti ki, és alapkutatásra munkaidejüknek csak 3 százalékát szánják. Az egyéb kategóriába sorolták a válaszadók a gyártást, az értékesítést, a gyártástechnológiai és alkalmazástechnológiai tevékenységet. Ezekre a tevékenységekre a kutatók munkaidejük 4 százalékát fordítják. A kutatók átlagosan idejük 2 százalékát töltik oktatással.

Kíváncsi voltam, hogy egyes vállalatok esetén az innovációk döntő többsége melyik kategóriába sorolható. Amennyiben a vállalatra legjellemzóbb innovációtípust vizsgálom, akkor elmondható, hogy a hazai vegyiparban leginkább a jelenlegi piac számára fejlesztenek ki új termékeket és technológiákat a cégek, hiszen átlagosan a cégek 39 százaléka jelölte meg ezt a kategóriát elsődlegesen (6. ábra). A vállalatok 31 százaléka fejleszt ki vállalata számára eddig még ismeretlen terméket és/vagy technológiát. A cégek 11 százaléka próbálja meglévő termékeit/technológiáit új piacokra bevezetni. A mintában 8 cég számára volt elsődleges innovációtípus a költségcsökkentés. Az elemzett vállalatok 5 százalékának irányul csupán az innovációs tevékenysége elsősorban világújdonságok kifejlesztésére, és szintén 5 interjúalany munkahelye foglalkozik fóként innovációs tevékenységében korszerüsítésekkel (6. ábra).

6. ábra

Vegyipari vállalatoknál

megvalósított legjellemzóbb innovációtípusok

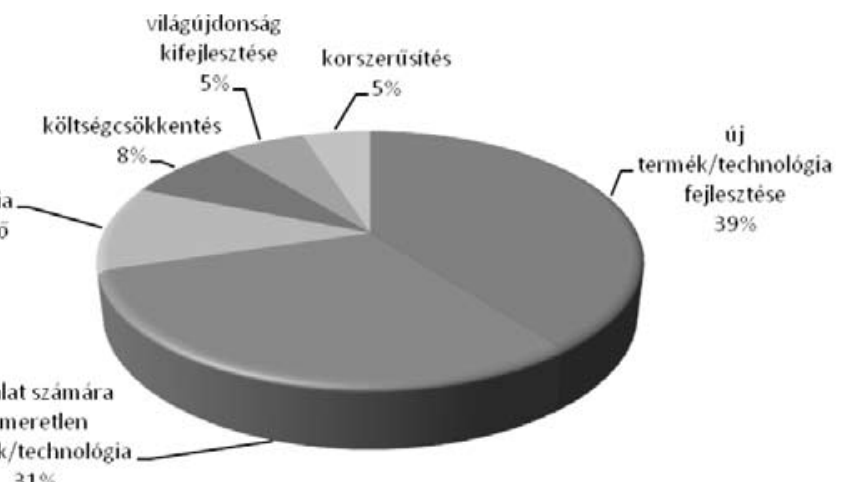

(Saját szerkesztés)

A mintában szereplố vállalatok 63 százalékánál az igazgató, illetve az ügyvezető igazgató az innovációs tevékenység fő koordinátora. Ez is azt sugallja, hogy a cégek számára kiemelt fontosságot képvisel az innováció, és a vegyipari cégek tevékenységében hangsúlyos szerepet kap az innováció, hiszen a vizsgált vállalatok 23 százalékánál külön kutatás-fejlesztési igazgató koordinálja az innovációs tevékenységet. 9 gazdálkodó szervezetnél a projektmenedzser, 5 vállalatnál pedig a múszaki és fejlesztési vezetô, valamint a foómérnök felelôs az innovációért.

Kíváncsi voltam, hogy a vállalatok honnan szereznek innovációra vonatkozó információt, tehát milyen információforrásokat használnak. A kérdésre adott válaszokat kétféleképpen lehet elemezni. Amennyiben a legfontosabb innovációs információforrásokat veszem csak figyelembe, akkor kizárólag csak az első́ helyen megjelölt válaszokat elemzem. Ebben az esetben a cégek több mint fele - 54 százaléka - elsôsorban az ügyfelek igényeinek próbál megfelelni, és a vevők kívánságának megfelelően hajtja végre innovációit. Másik fontos információforrásnak tekinthetô a szakirodalom, hiszen a cégek 19 százaléka említette a szakirodalmat az elődleges innovációs ötlet forrásaként. 8 vállalat nyilatkozta azt, hogy az anyavállalatuktól szereznek elsósorban innovációra vonatkozó információt. A cégek 6 százaléka kutatóintézetektôl vásárol innovációs ötletet, illetve részeredményeket. A beszállítókat, valamint a vásárokat és kiállításokat 5-5 cég említette elsố helyen. 
Más eredményre jutottam, amikor megengedtem a kérdoóivet kitöltóknek, hogy rangsor szerint több válaszlehetôséget is bejelölhetnek. Az ügyfelek, vevók, valamint a szakirodalom került ekkor is az elsô és második helyre az innovációs információforrásokban. A válaszok súlyozott átlagát tekintve harmadik helyen viszont már a vásárok, kiállítások szerepelnek, sốt a versenytársakat is negyedik helyre sorolták a válaszadók. $\mathrm{Az}$ internet csak a beszállítókat és a kutatóintézeteket követően jelentkezik innovációs információforrásként, és a cégek anyavállalata pedig utolsó helyre került a feleletek súlyozott átlagát vizsgálva.

Összefoglalva elmondható, hogy a vegyipar olyan iparágnak tekinthetô, ahol az innovációs együttmúködés célja és fókusza egészen specifikus, így érdemes azt más ágazatoktól elkülönülten vizsgálni. Az elemzés középpontjában a vállalatközi kooperációból származó előnyök vizsgálata állt, és részletesen kitértem az együttmúködési megállapodások és együttmúködési formák vizsgálatára is. A mai tudás- és tókeintenzív kutatási körülmények között elengedhetetlen a vegyipari vállalatok számára, hogy innovációs folyamatuk során ne vonjanak be külső erốforrást. Ezek az innovációs inputok vállalatközi kapcsolatok kiépítése és folyamatos fenntartása által válhatnak biztonságos és megbízható erőforrássá. A vegyiparban tevékenykedő cégek számára kiemelt jelentôséget képvisel a megbízhatóság és a korábbi jó tapasztalat. Ezt a kutatási eredmények is hứen alátámasztották, hiszen a vállalatközi innovációs kapcsolatok kialakítása során a személyes ismeretség kritikus jelentőséggel bírt.

\section{Felhasznált irodalom}

Achilladelis, B. - Antonakis, N. (2001): The dynamics of technological innovation: the case of the pharmaceutical industry. Research Policy, 30, p. 535-588.

Albach, H. - Audretsch, D.B. - Fleischer, M. - Greb, R. Höfs, E. - Röller, L-H. - Schulz, I. (1996): Innovation in the European chemical industry. Wissenschaftszentrum Berlin für Sozialforschung, FS IV 96-26, Berlin

Auster, E.R. (1987): International corporate linkages: dynamic forms in changing environments. Columbia Journal of World Business, Vol. 22, No. 2, p. 3-13.

Becker, S. - Whisler, T. L. (1967): Innovative organisation: a selective view of current theory and research. The Journal of Business, Vol. 40, No. 4, p. 462-469.

Borsi, B. (2004): A technológiai megújulás, az innováció és a kutatás-fejlesztés mint versenyképességi tényezôk a magyar gazdaságban. PM Füzetek, 6. szám

Botazzi, L. - Peri, G. (2003): Innovation and spillovers in regions: evidence from European patent data. Europpean Economic Review, 47(4), p. 687-710.
Camagni, R. (1991): Local 'milieu', uncertainty and innovation networks: towards a new dynamic theory of economic space. in: Camagni, R. (szerk) (1991): Innovation networks. Belhaven Press, London, p. 121-144.

Chesnais, F. (1988): Multinational enterprises and the international diffusion of technology. in: Dosi, G. Freeman, C. - Nelson, R. - Silverberg, G. - Soete, L. (szerk) (1988): Technical change and economic theory. Pinter, London, p. 496-527.

Contractor, F.J. - Lorange, P. (1988b): Cooperative strategies in international business. Lexington Books, Lexington, MA

Cravens, D.W. - Shipp, S.H. - Cravens, K.S. (1994): Reforming the traditional organisation: the mandate for developing networks. Business Horizons, July-August, p. 19-28.

Edquist, C. (2005): Systems of innovation - perspectives and challenges. in: Fagerberg, J. - Mowery, D. - Nelson, E. (szerk.): The Oxford handbook of innovation. Oxford University Press, Oxford, p. 181-208.

Freeman, C. (1991): Networks of innovators: a synthesis of research issues. Research Policy, Vol. 20., No. 5., p. 499-514.

Haeffner, E.A. (1973): The Innovation process. Technology Review, March/April, p. 18-25.

Hagedoorn, J. (2002): Inter-firm R\&D partnerships: an overview of major trends and patterns since 1960. Research Policy, 31(4), p. 477-492.

Hagedoorn, J. (1990): Organisationel modes of inter-firm cooperation and technology transfer. Technovation, Vol. 10, No. 1, p. 17-30.

Hagedoorn, J. (1989): Organisational modes of inter-firm cooperation and technology transfer. MaastrichtEconomic Research Institute on Innovation and Technology, Working Paper Number: 89-004, April, Maastricht

Hagedoorn, J. - Schakenraad, J. (1989): Some remarks on the cooperative agreements and technology indicators (CATI) information system. MERIT, April, 89-010, Maastricht

Harrigan, K.R. (1985): Strategies for joint ventures. Lexington Books, Lexington

Holt, K. (1983): Product innovation management. Butterworths, London

ICEG EC (International Center for Economic Growth European Center) (2004): A vegyipar helyzete és kilátásai Magyarországon, http://www.icegec.hu/hun/ elemzesek/agazati/docs/fulls/vegyipar.pdf

Iványi, A. - Hoffer, I. (2004): Innovációs folyamatok menedzsmentje, Aula Kiadó, Budapest

Killing, J.P. (1983): Strategies for joint venture success. Croom Helm Ltd., Kent

Knight, K. (1967): A descriptive model of the intra-firm innovation process. Journal of Business, Vol. 40, October, p. 478-96.

Olvasó, Á (2007): A magyar vegyipar 100 éve, az olajipar és petrolkémiai ipar fejlődése, Centenáriumi vegyészkonferencia, május 29. - június 1., Sopron, előadásanyag, www.polipack.hu/_files/a_vegyipar_100_eve.ppt 
Powell, W. - Grondal, S. (2005): Networks of innovation. in: Fagerberg, J. - Mowery, D. - Nelson, R. (szerk.): The Oxford handbook of innovation. Oxford University Press, Oxford, p. 56-85.

Quinn, J.B. (1992): Intelligent enterprise. Free Press, New York, NY

Rogers, E.M. (1983): Diffusion of innovations. 3rd ed., Free Press, New York, NY

Rogers, E.M. - Schoemaker, F.F. (1971): Communication of innovations: a cross-cultural approach. The Free Press, New York, NY

Seufert,A.-vonKrogh,G.-Bach,A.(1999):Towardknowledge networking. Journal of Knowledge Management, Vol. 3, No. 3, p. 180-190.
Szépvölgyi, J. (2005): Lehet-e húzóágazat a vegyipar? NKTH Innovációs Tavasz előadásanyag, június 1.

Szépvölgyi, J. (1999): Vegyipar - ezredfordulós pillanatfelvétel, Magyar Tudomány, 6. szám p. 666-681.

Trenti, S. (1996): Cooperation agreements in an evolutionary framework: a case of the electronic industry. BETA, University Louis Pasteur, Strasbourg

Zaltman, G. - Duncan, R. - Holbeck, J. (1973): Innovation and organization. Wiley, New York http://ecoline.hu/ piac/20101001_vegyipar_elemzes.aspx

\section{Szerzóinknek}

A Vezetéstudomány a Budapesti Corvinus Egyetem Gazdálkodástudományi Karának havi, referált folyóirata. A lapban a vezetési és gazdálkodási tudományterületekhez kapcsolódó témakörök elméleti és gyakorlati kérdéseit elemző és vizsgáló írások jelennek meg. A szerkesztőség (robert.becsky@uni-corvinus.hu) elektronikus formában kéri az írásokat.

A cikkeket elektronikus levélben (MS Word fájl formátumban) lehet a szerkesztőséghez eljuttatni. A Vezetéstudományban megjelent cikkek magyar és angol nyelvü összefoglalói elérhetőek a http://www.vezetestudomany.hu és a http://vezetestudomany.hu címeken.

A lap tudományos folyóirat, ezért szövegközi forráshivatkozások és ezek jegyzéke nélküli írásokat nem jelentet meg. A Vezetéstudományban megjelentetni szándékozott kéziratok szerzőitől az alábbi követelmények figyelembevételét kérjük:

- A cikkek szokásos terjedelme a hivatkozásokkal, ábrákkal és táblázatokkal együtt 20-24 oldal, 1,5-es sortávolsággal (12-es betüméret, Times New Roman betütípus).

- A cikkek első oldalának alján tüntessék fel a szerző foglalkozását, munkahelyét és beosztását, elektronikus levelezési címét, a tanulmány elkészítésével kapcsolatos információkat és az esetleges köszönetnyilvánításokat.

- A kézirathoz csatolandó egy magyar nyelvú és lehetőség szerint egy angol nyelvú rövid összefoglaló (200 szót nem meghaladó terjedelemben), valamint a cikk fô témaköreit megnevező kulcsszavak jegyzéke.

- Kiemeléshez félkövér és dólt betü használható, aláhúzás nem. Jegyzeteket lehetőleg ne használjanak, amennyiben azok feltétlenül szükségesek, szövegvégi jegyzetként adják meg.

- A táblázatoknak és ábráknak legyen sorszáma és címe, valamint - átvett forrás esetén - pontos hivatkozása.

- Az ábrákat és a táblázatokat a kézirat végén, külön oldalakon, sorszámmal és címmel ellátva kérjük csatolni, helyüket a szövegben egyértelmúen jelölve (pl. „Kérem az 1. táblázatot kb. itt elhelyezni!").
- A szövegközi bibliográfiai hivatkozásokat zárójelben, a vezetéknév és az évszám feltüntetésével kérjük jelölni: pl. (Veress, 1999); szó szerinti, idézőjeles hivatkozás esetén kiegészítve az oldal(ak) számával (pl. Prahalad - Hamel, 1990: 85.).

- Amennyiben egy hivatkozott szerzőnek több bibliográfiai tétele van ugyanazon évben, ezeket 1999a, 1999b stb. módon kell megkülönböztetni.

- A felhasznált források cikk végén elhelyezett jegyzékét ábécérendben kérjük, a következő formában:

1. példa (könyv): Porter, M.E. (1980): Competitive Strategy; New York: The Free Press

2. példa (folyóiratcikk): Prahalad, C.K. - Hamel, G. (1990): The Core Competence of the Corporation; Harvard Business Review, május-június, 79-91. o.

A formai követelmények fentiekben érvényesített, ún. „Harvard” rendszeréról (más néven „szerzőlév” vagy „,név/dátum” hivatkozási módszerról) részletes tájékoztatást nyújtanak az alábbi WEB-címeken elérhető források.

Havi folyóirat lévén és a megjelenés átfutási idejének csökkentése érdekében a Vezetéstudomány kefelevonatot nem küld, elfogadás előtt azonban a szerzóknek egyeztetés céljából elküldi a cikk szerkesztett változatát.

2009. januártól a Vezetéstudományban publikált cikkek elérhetôek az ISI Eme ,www.securities.com” internetcímen található strukturált on-line információs adatbázisban. 2009 júniusától a Vezetéstudományban közölt írások elérhetôek az EBSCO Academic Search Complete adatbázisában a http://web.ebscohost.com/ehost/search? vid=20\&hid=102\&sid $=747 a 764 f-362 f-4683-9255-4 e 54 f 5 b a 0 d f 7 \% 40$ sessionmgr 112 oldalon is.

Külön kívánságra 2004-ig visszamenóleg az összes korábbi kiadás publikációit elektronikus változatban is elküldjük.

Ha a szerző nem járul hozzá cikkének eseti kérésre, elektronikus úton való továbbadásához, kérjük, előre közölje ezt. 